\title{
The Brazilian Drug Policy Situation: The Public Health Approach Based on Research Undertaken in a Developing Country
}

\author{
Marcelo Ribeiro, MSc, $\mathrm{PhD},{ }^{1,2,3}$ \\ Luciane Ogata Perrenoud, ${ }^{1}$ \\ Sérgio Duailibi, MD, $\mathrm{PhD},{ }^{1,3}$ \\ Lígia Bonacim Duailibi, MSc, ${ }^{1}$ \\ Clarice Madruga, $\mathrm{MSc}, \mathrm{PhD},{ }^{3}$ \\ Ana Cecília Petta Roseli Marques, MD, PhD, ${ }^{3,4}$ \\ Ronaldo Laranjeira, $\mathrm{MD}, \mathrm{PhD}^{1,3,5}$
}

\begin{abstract}
Brazil is one of the largest countries in the world, and is home to significant demographic, social and cultural diversity, as well as intense regional inequality. The country has successfully tackled many of these challenges, and the positive repercussions of these developments on the health care system have been particularly evident over the past two decades. Significant advances have also been made in terms of drug policies. The Brazilian tobacco control policy is one of the most advanced in the world and has helped the country to reduce the number of smokers by one half over the past 30 years. However, the alcohol market remains unregulated and regional alcohol control policies are still very inconsistent, leading to increased alcohol consumption due to a combination of advertising, low cost and high availability. The recent increase in the use of illegal psychoactive substances has also led to higher rates of domestic and urban violence, crime and mortality. The public health system offers several treatment options for individuals with substance disorders, but important services, such as detoxification centers, have yet to be implemented in the country. The national debate about drug policy is still very
\end{abstract}

\footnotetext{
${ }^{1}$ Federal University of São Paulo (UNIFESP), São Paulo, Brazil.

${ }^{2}$ Reference Center for Alcohol, Tobacco and other Drugs (CRATOD) - São Paulo State Government, São Paulo, Brazil.

${ }^{3}$ National Institute of Science and Technology for Public Policies in Alcohol and Drugs (INPAD), Federal University of Sao Paulo (UNIFESP), São Paulo, Brazil.

${ }^{4}$ Brazilian Association for the Study of Alcohol and Other Drugs (ABEAD), Brazil.

${ }^{5}$ Special Advisor for Drug Policy (Programa Recomeço), São Paulo State Government, Brazil.

Corresponding Author Contact Information: Marcelo Ribeiro at marcelo@uniad.org.br; Unidade de Pesquisa em Álcool e Drogas, UNIAD, UNIFESP, Rua Borges Lagoa, 570, $8^{\circ}$ andar, conjunto 802, 04038-020, São Paulo (SP), Brazil.
} 
theoretical in nature and lacks the technical foundation offered by scientific research. In conclusion, in spite of the significant progress made over the past three decades, Brazil still has a long road to travel before developing a consistent and effective drug policy. The aim of the present article was to review the relevant and interesting developments in Brazilian drug policy over recent decades and to discuss framework for future developments in terms of legislation in the area.

Key Words: Drug policy, substance abuse, epidemiology, Brazil, tobacco abuse, alcohol abuse, substance abuse treatment centers

Recommended Citation: Ribeiro M, Perrenoud LO, Duailibi S, Duailibi LB, Madruga C, Marques ACPR, Laranjeira R. The Brazilian drug policy situation: the public health approach based on research undertaken in a developing country. Public Health Reviews. 2014;35: epub ahead of print.

\section{INTRODUCTION}

Brazil is a continent-sized country with nearly 191 million inhabitants (Figure 1). ${ }^{1}$ The country is one of the five members of the BRICS group (Brazil, Russia, India, China and South Africa), and has the seventh largest Gross Domestic Product (GDP) in the world, amounting to approximately USD \$2.252 trillion. $^{2}$

Over the past three decades, the Human Development Index (HDI) in Brazil increased from 0.522 to $0.730(20 \%)$. ${ }^{3}$ However, the country still struggles with great structural problems, as well as deep social and regional inequality (Figure 2): ${ }^{4}$ while the HDI in the South and Southeast Regions is similar to that of Portugal (mean $=0.85$ ), the HDI in some states in the North and Northeast is approximately 0.7, comparable to that of countries such as Indonesia and Botswana. ${ }^{3}$ Almost half the Gross National Product is produced by two states in the country (São Paulo and Rio de Janeiro). ${ }^{5}$ Nevertheless, the HDI reported by Caucasians in those two states is among the 40 highest in the world, while the HDI of the Black population from the same area is only among the 70 highest. $^{6}$

Although Brazil has been a republic for 120 years, its government was run under coups or state of emergency legislation for at least half this period. In fact, the country has had only two periods of stable democracy longer than two decades since $1889 .^{7}$ Since the reinstatement of a democracy after 21 years of a military dictatorship (1964-1985) and the promulgation of a new constitution in 1988 , the country has been able to maintain civil social order, as well as improve and strengthen its democratic institutions. ${ }^{8}$ However, as previously mentioned, economic inequality and social exclusion still compromise the quality of the Brazilian democracy. ${ }^{9}$ Therefore, in spite of growing recognition by the international community, ${ }^{10}$ democracy in 
Brazil is still considered "flawed". ${ }^{11}$ This is especially due to the lack of political culture and participation amongst a considerable percentage of the population, which still has limited access to health and education services, and are alienated from political decisions. ${ }^{12,13}$

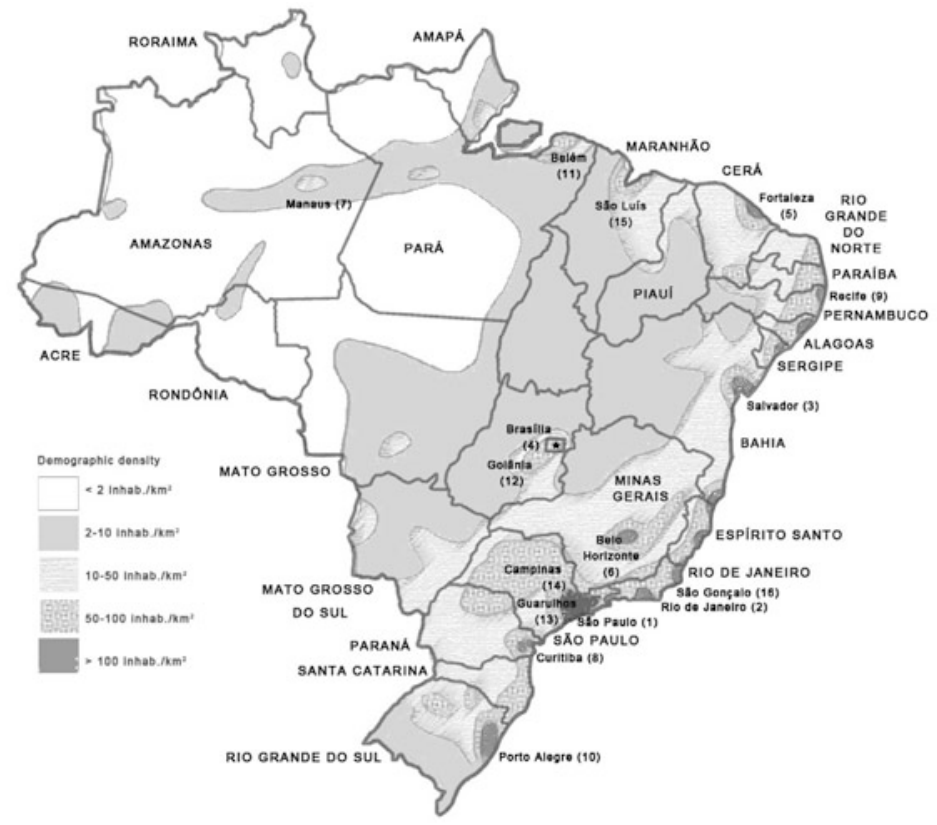

Fig. 1. Map with political divisions and demographic density of Brazil. The country has 27 states and a Federal District (Brasília). ${ }^{1}$ Brazilian cities with more than one million inhabitants are shown. The majority of the Brazilian population resides in coastal areas and in the Southeast and South Regions.

It is within this social context that the present article aims to describe psychoactive substance (PAS) use, as well as Brazilian public policy on alcohol, tobacco, prescription drugs and illicit drugs, and the challenges related to the production and application of scientific research on the topic by municipal, state and federal institutions. The possible causes of these phenomena will also be discussed in the present study.

It is important to note that the authors' research group, the National Institute of Science and Technology for Public Policy on Alcohol and Other Drugs (INPAD), has been testing and developing models of drug policy, conducting epidemiological surveys to determine the magnitude of alcohol and drug related problems in Brazil, and has been actively involved in drug policy debates since $1994 .{ }^{14}$ 
(A)

(B)

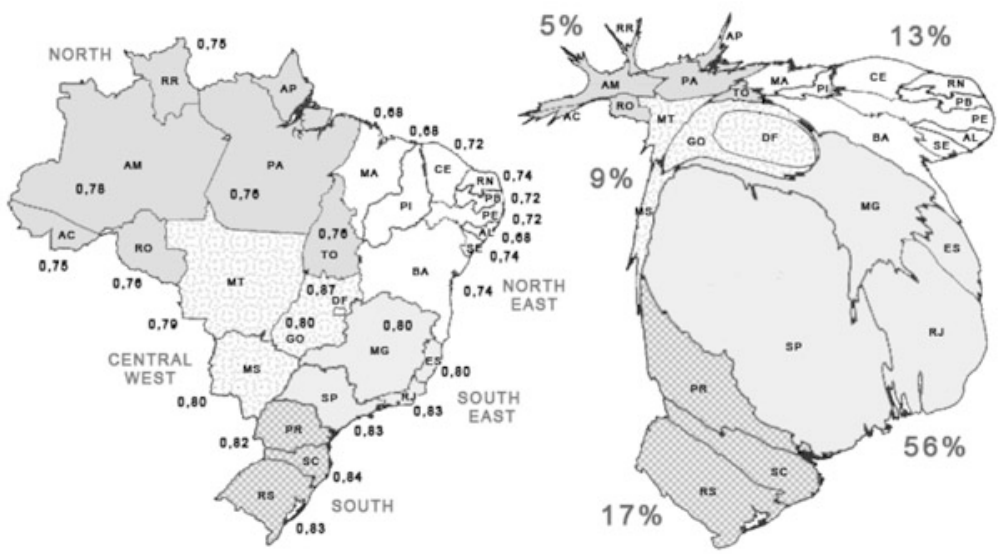

Fig. 2. (A) Brazilian political map with the Human Development Index (HDI) for each state; the best scores are observed in the South and Southeast Regions, while the worst are located in North and Northeast Regions. ${ }^{3}$ (B) Contributions of different Brazilian Political Regions to the Gross Domestic Product (GDP) (2012): the South and Southeast Regions produced $73 \%$ of the country's wealth. ${ }^{5}$

\section{METHODS}

The present authors reviewed major research articles regarding: (1) the epidemiology of PAS use in Brazil, (2) experimental testing of public policy models, and (3) the assessment of the efficacy or effectiveness of measures implemented by municipal, state and federal government agencies. Articles were retrieved from the following databases: MEDLINE*; LILACS (LatinAmerican and Caribbean Literature in Health Sciences); and the PanAmerican Health Organization Virtual Health Library (BVS).** The searches were conducted using combinations of the terms "alcohol", "tobacco", "marijuana", "cocaine", "crack cocaine", "prescription drugs", "amphetamines", "methylphenidate" and "illicit drugs" with words related to the main theme of the present article: "Brazil", "public policy" and "drug policy".

\footnotetext{
* Available from URL: http://www.pubmed.com

** Available from URL: http://www.bireme.br
} 
The review mainly comprised articles published in English, although some articles in Portuguese were included in the following cases: (1) official documents released by international organizations-such as the United Nations and its agencies, state and federal Executive Branch departments and agencies, or planning and statistics departments; (2) municipal, state and federal laws approved by their respective legislative branches; (3) articles regarding topics that are relevant to the present review but have not been published in English; and (4) articles on the main theme of the present review, published in Portuguese in journals indexed in the MEDLINE or LILACS databases, whose relevance or the absence of similar publications in English justified their inclusion in the review.

\section{RESULTS}

Findings regarding Brazilian public policy on alcohol, tobacco and other PASs were organized and described in the present review according to the following criteria: (1) the reviewed studies were divided into categories according to the most commonly used PASs in Brazil, namely: tobacco, alcohol, prescription drugs and illicit drugs; (2) the policy for each substance is described in the text in decreasing order of comprehensiveness and effectiveness; and (3) the substance abuse treatment network in Brazil, which was recently established and is still growing, is discussed in a separate subsection.

\section{Tobacco}

Tobacco use in Brazil increased significantly in the 1980s, and as of 1989, 34.8 percent of Brazilians reported smoking cigarettes. ${ }^{15}$ In the 1990 s, however, federal tobacco control laws became more stringent,${ }^{16}$ and tobacco specific taxes of 41.3 percent went into effect starting in 1990. Text and pictorial warnings of the dangers of tobacco use began to be printed on cigarette boxes in 1996 and 2001 respectively, and in 2000, the tobacco industry was prohibited from providing financial support to or advertising at cultural events. In 2001, tobacco dependence treatment programs were implemented, primary health professionals were trained to help individuals to give up smoking, a tobacco Quitline was established, and there was increased control over the production and distribution of tobacco products. ${ }^{17}$ Additionally, in 2006, new tax laws increased the prices of Brazilian cigarettes to twice their cost in 1989 (after taking inflation into account). ${ }^{17}$ 
A law banning smoking in public places-especially nightclubs, shopping malls and restaurants-was implemented only in the 2000s, partly due to lobbying by the tobacco industry. ${ }^{18}$ Since then, municipal laws banning environmental tobacco smoke (ETS) have been approved in Rio de Janeiro in 2008, ${ }^{19}$ and in São Paulo in 2009. In fact, the latter state, which has the largest population in Brazil, with 40 million inhabitants, was the first to ban smoking indoors in workplaces. ${ }^{20}$ Lastly, in 2011, restrictions on indoor ETS were enacted into nationwide law. ${ }^{21}$

Some other measures have been taken by the National Agency for Sanitary Surveillance (ANVISA), such as the prohibition of flavor additives in cigarettes, and the use of terms such as "low tar," "light" or "mild" on cigarette packs. ${ }^{22}$

Brazil was an active participant in the World Health Organization Framework Convention on Tobacco Control (WHO FCTC) negotiations in 2003 , where it was considered to have a leadership role as a "soft power" due to its successful tobacco control policies and their dissemination to other developing countries, especially in Latin America. ${ }^{23}$ The WHO FCTC was approved by the National Congress in 2005 and promulgated by the Brazilian President in the following year. ${ }^{24}$

It was not long before the combined impact of these measures was seen, as the proportion of smokers in Brazil decreased from 35 percent in 1989 to 22 percent in $2003 .{ }^{25}$ These data were confirmed by a survey that indicated a 50 percent decrease in smoking in Brazil between 1989 and 2008 , by which time only 17 percent of the population reported smoking. ${ }^{17,26}$

As for tobacco treatment services, Raw, et al. observed that the country was still struggling to implement a successful tobacco control program in its primary health system, such that new health centers would have to be developed to meet demand. Furthermore, the access to medication for nicotine dependence was much too centralized, leading to delays in supply and decreasing the access to these medications. Lastly, the Quitline appeared to have a relatively low impact on smoking cessation. ${ }^{27}$

Other situations are considered worrisome by Brazilian researchers and health workers include the lack of information regarding "alternate" tobacco products, such as water pipes, which are considered less harmful by a large sector of the population ${ }^{28}$; the lack of monitoring of tobacco industry activities; and the need to intensify policy on tobacco taxes and prices. ${ }^{29}$

\section{Alcohol}

Alcohol use in Brazil has led to a number of serious problems, such as the fact that 25 percent of adults (approximately 32 million people) have some 
sort of alcohol-related disorder, and nine percent of these individuals (approximately 11 million Brazilians) are alcohol dependent. ${ }^{30}$ Moreover, studies suggest that 30 percent of the population engages in binge drinking. ${ }^{31}$ Since a large part of the population (48\%) reported to abstain from alcohol, it appears that most of this substance in Brazil is consumed by a small number of heavy drinkers. In fact, studies suggest that 2.5 percent of these individuals consume 15 percent of the alcohol sold in the country, meaning that ten percent of the heaviest drinkers consume as much as 45 percent of the alcohol drunk in Brazil. ${ }^{32}$

Surveys of adolescents found that half had consumed alcohol in the past year, and one third reported to drinking regularly. ${ }^{33}$ School surveys showed that 59 percent of middle school students (10-13 years old) and 81 percent of high school students (14-18 years old) have tried alcohol at least once in their lives. ${ }^{34}$

The WHO guidelines for public policy on alcohol are widely disseminated in the Brazilian scientific community. ${ }^{35,36}$ However, the sale of alcoholic beverages in Brazil is not regulated by the government, is generally driven by market forces, ${ }^{37,38}$ and no special sales license is required. ${ }^{39}$ In 2005 , the number of alcohol retailers was approximately two million-a total of one establishment for every 140 adult Brazilians, according to a study presented by Seligman at the International Forum of Quality of Life and Health - Alcoholism: Who Pays the Bill? in Porto Alegre, Brazil. ${ }^{40}$ In regions with high social exclusion, such as the slums (known as "favelas") of São Paulo, the concentration of alcohol retailers can reach unimaginable levels, with some locations documenting 29 establishments per kilometer or one for every 12 homes. $^{41}$

Although selling alcohol to underage persons is prohibited by federal law, studies show that most adolescents (approximately 80\%) have at some point purchased alcoholic beverages without being asked for identification. ${ }^{42}$ Only recently, in 2011, did the state of São Paulo approve a law that held the owners of bars, restaurants, nightclubs, supermarkets and convenience stores responsible for selling alcohol to underaged persons, or for allowing these individuals to consume alcohol on their premises. ${ }^{43}$

\section{Drinking and Driving}

To date, there are over 87 million vehicles registered in Brazil. ${ }^{44}$ Traffic accidents are among the most common causes of violent death in the country - second only to homicide-and are responsible for more than 150,000 injuries every year, of which 35,000 are fatal, leading to a cost of USD $\$ 14$ billion per year. ${ }^{45}$ 
The mortality rate for traffic accidents in Brazil is 20 per 100,000 inhabitants, which is three to four times higher than that observed in countries such as Canada, Japan and Sweden. ${ }^{46}$ A considerable portion of these cases has been associated with alcohol consumption. In fact, blood alcohol concentrations (BAC) near or above $0.6 \mathrm{~g} / \mathrm{l}$ were found in approximately half of all autopsies performed as part of scientific studies in São Paulo $(n=1,555),{ }^{47}$ Rio de Janeiro $(n=348){ }^{48}$ and Brasília $(n=442) \cdot{ }^{49} \mathrm{~A}$ driver survey also found that over one third of participants had driven while intoxicated on at least one occasion..$^{39,50}$

Alcohol-related problems are also common among truck drivers. The number of trucks registered in Brazil is estimated to be approximately 1.85 million, and these vehicles are responsible for almost 60 percent of the total tonnage of products transported. ${ }^{51}$ Studies with convenience samples have found that over half of participants had driven after drinking at least once in their lives, and that approximately one quarter of these individuals drink on a daily basis. ${ }^{46}$

In 2008, the federal government set the legal BAC limit at $0.02 \mathrm{~g} / 1,{ }^{52}$ which led to an immediate reduction in hospital admissions (28\%), health care costs (39\%) and deaths related to traffic accidents (13\%). ${ }^{53} \mathrm{~A}$ study in the City of São Paulo compared breathalyzer tests $(n=3,854)$ conducted on Friday nights from 11 p.m. to 3 a.m. between 2007 and 2009, and found a 45 percent reduction in positive results over this interval. ${ }^{54}$ In spite of the positive impact of the new legislation, the lack of monitoring mechanisms, equipment (breathalyzers), and police training - as well as a feeling of impunity by a significant number of drivers-are constant threats to the success of public policy in Brazil. ${ }^{55}$ Consequently, legislation is often imprecise and not effectively implemented. ${ }^{56}$

\section{The Alcohol Industry}

Brazil is the fourth largest producer of alcoholic beverages and is home to the largest brewery in the world, the Americas Beverage Company (AMBEV). AMBEV accounts for over half of the Brazilian market for beer and is one of the three largest companies in the country. ${ }^{32,57}$ It makes very high annual profits and has tremendous political influence in the country. ${ }^{58}$ A clear example of this situation was the government decision to revoke the prohibition of alcoholic beverages in soccer stadiums during the 2014 World Cup matches, "at the request" of FIFA and its sponsors. ${ }^{59}$ Another example involves the broadcasting of advertisements for alcoholic beverages. In the early 2000 s, civil organizations requested the approval of a ban on alcoholic beverage advertisements. ${ }^{37}$ However, in spite of their 
efforts, advertisements of fermented alcoholic beverages (alcohol content $<$ $13 \%$ ) are still allowed between 9 p.m. and 6 a.m..$^{21}$

In anticipation of more government attempts to regulate alcohol marketing, the alcoholic beverage industry created its own advertising regulations, such as forbidding sexual content, cartoons, or the participation of actors younger than 25 years in any advertising campaign. ${ }^{37}$ Vendrame \& Pinsky conducted a systematic review on the topic and found that the alcohol industry's self-regulation of advertising does not effectively prohibit advertising directed at children and adolescents. ${ }^{60}$

The industry also finances leading academic researchers to establish programs to disseminate messages regarding "responsible drinking" and "alcohol and health," 61 to use scientific arguments and counter-arguments to influence public policy, and to establish a positive public image. ${ }^{62}$ When these measures were first introduced, there was intense academic debate regarding their legitimacy and ethical implications..$^{38,39,63}$

\section{Closing of Bars: An Isolated Experience in Brazil}

Diadema is an industrial city located in the metropolitan region of São Paulo, and has approximately 360,000 inhabitants. In 1999, the city had one of the highest homicide rates in the country (103 for every 100,000 inhabitants), and 65 percent of these incidents occurred in or near bars. ${ }^{64}$ In 2002, a law mandating bars to close at 11 p.m. and establishing a rigorous program to monitor its implementation was drafted by the mayor's office and approved by the Diadema Municipal Chamber. Following the passing of this legislation, homicide rates between January 1995 and July 2005, and incidents of violence against women between July 2000 and July 2005 were examined. It was found that the monthly homicide rate in Diadema, which had remained stable at 22 per month between 2000 and 2002, reduced by 61 percent, falling abruptly to 12 and remaining at this level for the following years (2002-2005). Monthly instances of violence against women also decreased from 48 to $25(52 \%){ }^{65}$

\section{Prescription Drugs}

Self-medication is extremely common in Brazil, ${ }^{66}$ and can be observed even in children and adolescents. ${ }^{67}$ A national survey found that the prevalence of anxiolytic and amphetamine drug use in Brazilian students between the ages of ten and 19 years $(n=50,890)$ in the past year was of 2.6 and 1.7 percent, respectively, and was almost twice as high in girls as in boys. ${ }^{34}$ 


\section{Benzodiazepines}

Benzodiazepines (BDZ) are among the most commonly prescribed medications in Brazil. ${ }^{68}$ Although BDZ sales are strictly and heavily regulated by the national health agency, studies with convenience samples suggest that approximately one fifth of users purchase these medications without a prescription. ${ }^{68} \mathrm{BDZ}$ are often (1) not adequately prescribed, (2) used for long periods of time, and (3) easily purchased without a medical prescription. ${ }^{69,70}$, Evidence of the indiscriminate prescription and use of $\mathrm{BDZ}$ can be found in studies of elderly individuals in Brazil. ${ }^{71}$

\section{Amphetamine Derivatives}

In Brazil, the abuse of oral, intravenous or smoked amphetamine derivatives is somewhat rare. However, the country has always been one of the largest consumers of amphetamine derivatives prescribed for obesity, such as femproporex, amfepramone and mazindol. ${ }^{72}$ The prescription and supply of these drugs is fraught with irregularities, such as indiscriminate prescription by physicians, drug formulas prohibited by ANVISA and illegal sales, especially by apothecaries. ${ }^{72,73}$

Another serious public health problem related to amphetamine derivatives is their use by truck and bus drivers in Brazil. Approximately one quarter of Brazilian truck drivers reported using amphetamines daily, while more than half used them very often ${ }^{46}$ The need to meet delivery deadlines was the most common argument to explain this pattern of drug use. The truck drivers also reported to generally acquiring amphetamines illegally in gasoline stations or pharmacies. ${ }^{48}$

These findings as well as the availability of safer options for treating obesity led ANVISA to pass a national ban on the sale of amphetamine derivatives. ${ }^{74}$ However, the impact of this measure on illegal drug markets, as well as on drug use and health in the Brazilian population has yet to be investigated.

Few studies have been conducted into the use of methylphenidate in Brazil. A review of articles regarding this drug published over the past ten years found that: (1) the national production of methylphenidate increased from $23 \mathrm{~kg}$ in 2000 to $226 \mathrm{~kg}$ in 2006; (2) the pharmaceutical industry provides funding for most Brazilian research on the topic; and (3) the benefits of these medications tend to be emphasized, while the risk of abuse and dependence are minimized. ${ }^{76}$ 


\section{Opiates}

Heroin use is extremely rare and practically non-existent in Brazil. However, doctors and nurses with easy access to opiates-fentanyl, propofol and meperidine - are more vulnerable to problems related to the improper use or abuse of these substances. ${ }^{77}$ In a study of a random and representative sample of anesthesiologists in the city of Belo Horizonte $(n=157)$, three percent of participants reported to having used opiates at some point in their lives. ${ }^{78}$ The Regional Medical Council of São Paulo (CREMESP) has a program in place to assist doctors with PAS dependence. Approximately 70 percent of users of this service are anesthesiologists with opiate dependence. ${ }^{77}$ To the authors' knowledge, no studies have been conducted on opiate use and complications in individuals who suffer from chronic pain.

\section{Illicit Drugs}

\section{Cannabis}

Epidemiological studies of representative samples of the Brazilian population found that approximately two to three percent of adult participants had used cannabis in the previous 12 months. ${ }^{78-80}$ The prevalence of cannabis use among Brazilian adolescents is approximately four percent ${ }^{78,80}$

According to the Second Brazilian National Alcohol and Drugs Survey (II BNADS), 29.7 percent of individuals who had used cannabis in the previous 12 months, that is, 0.75 percent of the Brazilian population or 1.1 million individuals between the ages of 15 and 64, met criteria for substance dependence. ${ }^{80}$ The same study showed that one third of individuals with cannabis dependence have unsuccessfully tried to stop their drug use, and one quarter report withdrawal symptoms.

Little is known about cannabis users who seek treatment in Brazil. In 2000, the Alcohol and Drugs Research Unit (UNIAD) at the Federal University of São Paulo (UNIFESP) established the first outpatient clinic designed specifically to assist individuals with cannabis dependence. This event breached the taboo regarding the association between cannabis and dependence, withdrawal symptoms or psychiatric and cognitive complications. ${ }^{81}$ Most patients who sought treatment in this referred clinic $(n=160)$ between 2003 and 2004 were employed middle-class males (mean age $=32$ years) with undergraduate-level education. These individuals had used cannabis for a mean of 15 years, had started to use the drug at approximately 16 years of age and had been using it on a daily basis since the age of 21. At the time of the survey, these individuals smoked an average of two cannabis cigarettes a day. ${ }^{82}$ 


\section{Crack and Cocaine}

Every year, approximately one third of the cocaine in South America is consumed in Brazil. ${ }^{83}$ To date, the country is also the largest consumer of crack cocaine in the world ${ }^{84}$ and the amount of this drug seized in Brazil tripled between 2004 and $2010 .^{85}$ According to the II BNADS, ${ }^{84} 2.2$ percent of the Brazilian population between 15 and 64 years of age had used some form of cocaine derivative in the previous 12 months. Intranasal cocaine use was reported by 1.7 percent of Brazilians ( 2.5 million inhabitants), and is five times more common in men (2.9). Approximately 0.8 percent of Brazilians between the ages of 15 and 64 (1.15 million inhabitants) reported to smoking cocaine in the form of crack, cocaine base paste or merla (a mixture of cocaine base paste and battery acid) in the past year.

Forty one percent of individuals who had used cocaine in the previous year had also met diagnostic criteria for drug dependence at some point in their lives ${ }^{84}$ Furthermore, associations between crack and cocaine use and the presence of psychiatric comorbidities, cognitive impairment, sexually transmitted diseases and involvement in illegal activities have also been documented in Brazil. 99,86 The relationship between the consumption of crack cocaine and urban violence will be discussed later.

\section{Intravenous Drugs}

The prevalence of intravenous drug use in Brazil is very low. According to Bastos, et al., approximately 0.035 percent of Brazilians who live in urban areas (approximately 50,000 individuals) used intravenous drugs in 2005, and the lifetime prevalence of intravenous drug use in Brazilians aged 15 to 49 years is around one percent (approximately 625,000 inhabitants). ${ }^{79}$ Cocaine is the most frequently used intravenous drug, although rare cases of intravenous opiate use (most commonly heroin) have also been reported in the literature. ${ }^{87}$

The incidence and prevalence of AIDS and Hepatitis C infections among injecting drug users (IDU) plummeted between 1982 and 2002,88,89 probably due to the syringe exchange programs established in Brazil in the 1990s, the change from intravenous to other drug administration methods and the high mortality rates among drug users..$^{90} \mathrm{~A}$ recent increase in intravenous drug use and in the incidence of AIDS among drug users has been reported in the southern region of the State of São Paulo, ${ }^{88}$ especially in poorer communities with less access to information. ${ }^{91,92}$ 


\section{Methylenedioxymethamphetamine}

There is an almost total lack of knowledge about the consumption of methylenedioxymethamphetamine (MDMA) in Brazil, but non-scientific evidence points to a breakthrough of this drug, especially among youth. ${ }^{93}$ Epidemiological data on MDMA use from representative samples of the Brazilian population are non-existent. Two descriptive studies ${ }^{94,95}$ with convenience samples selected from ravers and night club-goers provided a limited profile of these users, without, however, seeking correlations with mental illness or clinical complications.

\section{Substance Abuse Treatment Network in Brazil}

\section{Historical Antecedents}

Throughout most of the $20^{\text {th }}$ century in Brazil, mental disorders were treated in large and run-down asylums, in which individuals remained for long periods of time — sometimes for the rest of their lives - receiving no formal medical attention, experiencing hunger, sleeping on hay mattresses, and subjected to all manner of humiliation. ${ }^{96}$

Toward the end of the military regime in Brazil (1978-1985), movements inspired by the ideas of the Italian psychiatrist Franco Basaglia (19241980) began to fight for the civil rights of patients and demand the closure of asylums. ${ }^{97,98}$ In 1990, Brazil signed the Caracas Declaration, ${ }^{99}$ and in 2001, the "Psychiatric Reform" (Law 10.216), which mandated the closure of all asylums and developed a community based support network, was approved by the National Congress. ${ }^{100}$

However, as of the early 2000s, there was an average of one public outpatient clinic for every 250,000 Brazilians, ${ }^{101}$ and most patients with mental disorders were still treated in hospitals. ${ }^{100}$ Outpatient clinics for substance disorders were also rare, and could only be found in some federal and state universities in large urban areas, such as São Paulo, Rio de Janeiro, Porto Alegre and Salvador. There were no detoxification centers, and assisted living and half-way houses were only isolated experiments. ${ }^{102}$

\section{Psychosocial Care Centers for Alcohol and Drugs}

In 1988, the new Brazilian Constitution implemented the Unified Health System (SUS), with the aim of providing free and universal health care for its citizens. ${ }^{4}$ Patients' first contact with the SUS is through the Family Health Strategies service (ESF), a community based outpatient program, which aims to provide basic treatment and prevention strategies and refers 
complicated cases to appropriate facilities. ${ }^{4}$ The law states that all Brazilian municipalities with up to 20,000 inhabitants should have one ESF. Cities with 20,000 to 70,000 inhabitants should additionally have Psychosocial Care Centers (CAPS I) to provide general assistance to individuals with mental disorders. Lastly, cities with over 70,000 inhabitants should also provide services specifically to individuals with substance disorders through Psychosocial Care Centers for Alcohol and Drugs (CAPS-AD). ${ }^{103}$

The CAPS-AD are multidisciplinary outpatient programs which provide treatment for individuals with PAS problems, and are responsible for the organization, management and training of all health care workers involved in the social reintegration of drug users. ${ }^{104}$ Currently, there is approximately one CAPS-AD for every 150,000 Brazilians, for a total of 260 centers throughout the country (Figure 3 ). ${ }^{105}$

\section{Outreach Programs}

Besides the CAPS-AD, the federal government has also developed an outreach program based on harm reduction strategies, known as "Consultórios de Rua" (Street Offices). According to the Ministry of Health, ${ }^{106}$ the goal of these services is to provide assistance to severe drug users, who often live under adverse circumstances. Street offices are generally staffed by at least one mental health professional, one basic health care provider and one social worker who provide on-site interventions using a mobile health van. As of 2010, Street Office programs were registered in 19 Brazilian capitals and 12 other cities (Figure 3). ${ }^{106}$ There are no epidemiological studies to date regarding the impact of Street Offices on the health and recovery of drug users.

\section{Detoxification Centers}

The critical shortage of hospital beds in Brazil has serious implications for the treatment of PAS users. Since the closing of asylums, relatively little has been done in the way of increasing the number of hospital beds in Brazilian health care facilities, ${ }^{107,108}$ especially those that cater to the needs of PAS users, such as detoxification centers within or outside of hospitals. According to the Subcommission on Social Policy regarding Substance Dependents, conducted by the Brazilian Senate, a total of 11,000 hospital beds are currently designated for the treatment of substance dependence, of which 9,000 allow a maximum stay of 48 hours. These results suggest that Brazilian hospitals only reserve 0.34 percent of the total number of beds that should be designated for substance dependents, according to WHO guidelines. ${ }^{109}$ 


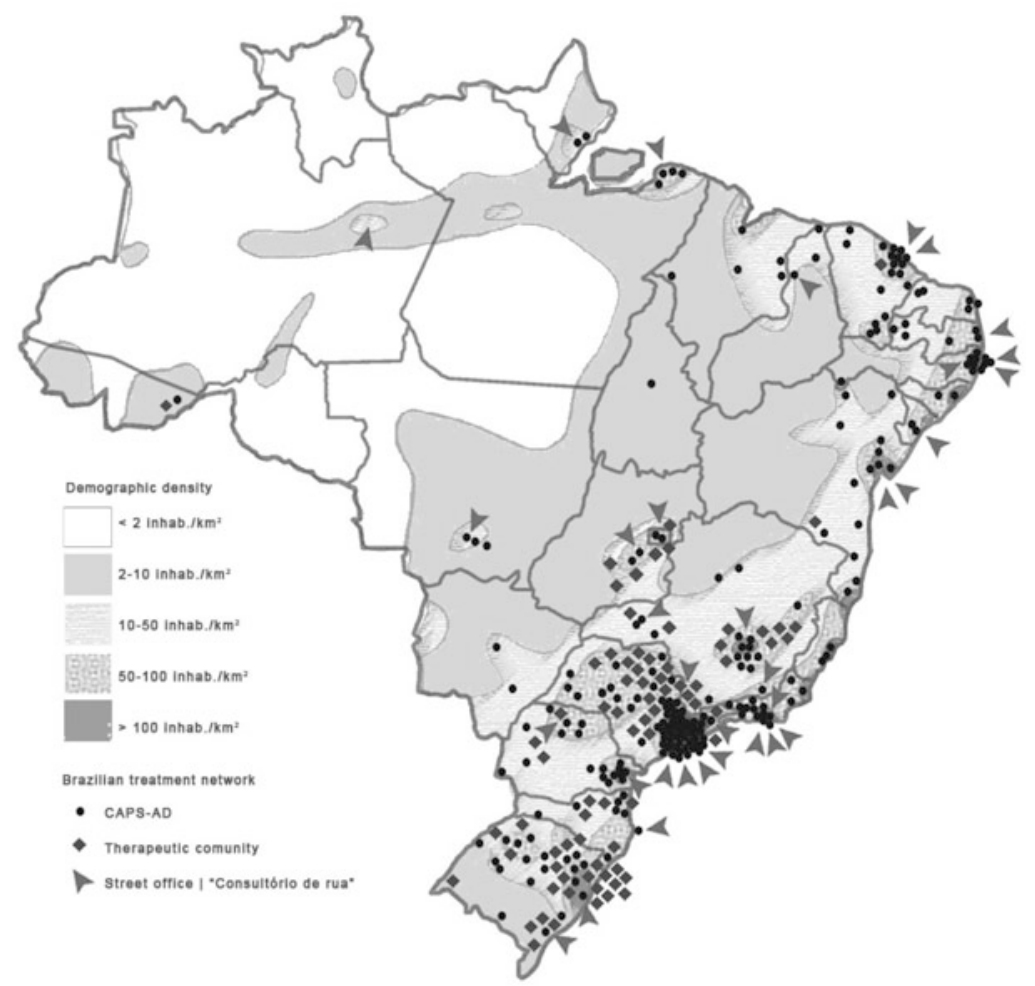

Fig. 3. The treatment network in Brazil, taking into account the demographic density of the country. ${ }^{103,105,111}$ Treatment services are notably scarce even for cities with medium population density and practically inexistent for thinly populated areas. The majority of services are concentrated in the Southeast and South Regions.

\section{Therapeutic Communities}

Brazil has a large network of therapeutic communities run by religious groups or former drug users. These communities began to be established in the early 1970s, and currently offer most of the assistance to individuals with disorders. ${ }^{110}$ In many cities in Brazil, therapeutic communities are the only treatment options for patients with substance use problems. ${ }^{111}$ These communities formed the Brazilian Federation of Therapeutic Communities (FEBRACT) and, since 2001, follow guidelines established by ANVISA (Figure 3). ${ }^{12}$ The services offered by therapeutic communities are based on three main pillars: voluntary admission, social interaction with peers, and spirituality. ${ }^{112}$ It must be noted, however, that most therapeutic 
communities are not affiliated with FEBRACT, maintain poor hygiene, are badly organized, and have no treatment guidelines. Some of those facilities are run based on strictly religious principles, while others use physical force and solitary confinement as punishment. ${ }^{113} \mathrm{~A}$ multicenter study of crack users from six Brazilian states and the Federal District who have been admitted to these communities is currently being conducted by INPAD.

\section{Rehabilitation and Social Support Structures}

Although mutual-help (Narcotics Anonymous (NA), Alcoholics Anonymous (AA), Tough Love) and religious support groups (Sobriety Ministries, Jewish Alcoholics, Chemically Dependent Persons and Significant-Others (JACS), etc.) are present in almost all Brazilian cities, they have not been sufficiently studied and are not integrated with the public health system. ${ }^{114}$

While there have been isolated attempts to implement assisted living facilities and temporary halfway houses in Brazil, such services have yet to be officially introduced in the country. ${ }^{102}$ Programs for income generation and reintegration to work are also embryonic, despite constant efforts by Brazilian researchers to highlight their importance for the recovery of users. ${ }^{115}$

\section{Drug Policy and Legislation}

There has been some form of legal regulation of PASs in Brazil since the first half of the $19^{\text {th }}$ century, however systematic legislation to control drug possession, use and trafficking was only approved during the Brazilian military dictatorship (1964-1985). The Drug Law (Law 6368) was implemented in 1976, and imposed prison sentences for these violations. ${ }^{116}$

When redemocratization began in 1985 and a new constitution was promulgated in 1988, there was a resurgence of discussion about the need for new drug legislation. These debates went on for 20 more years, until a new Drug Law (Law 11.343) was approved in 2006. According to this law, drug possession was still considered a criminal act, but was punished by community service as opposed to custodial sentences. ${ }^{116,117}$

Today, drug laws in Brazil are administered by the National System of Public Policies on Drugs (SISNAD), which comprises the National Secretary on Drug Policy (SENAD). SENAD is affiliated with the Ministry of Justice and the National Council on Drug Policies (CONAD), which report directly to the president's office. ${ }^{117}$

\section{Narcotraffic and Violence}

Drug trafficking has deeply affected social, political and economic life in Brazil and it is also intrinsically associated with organized crime, violence 
and homicide in the metropolitan areas of the country. ${ }^{118-121}$ Concurrently, the Brazilian social fragility due to its social discrepancies-Brazil's Ginicoefficient of inequality, which measures economical disparities, is the tenth highest in the world ${ }^{122}$ - further increases its vulnerability to illegal drug commerce, guns, corruption and the violence associated with them. ${ }^{121}$

Most notably, crack cocaine was first detected in Brazil inside abandoned and run-down neighborhoods neglected by public services, which became focal points for drug use and dealing, and have been nicknamed "cracolândias" (cracklands). When combined, the number of inhabitants and regular frequenters of the São Paulo crackland can reach up to 2,000, especially at night when drug activity in the neighborhood is most intense. ${ }^{123}$

These individuals tend to have unstable living arrangements, are often involved in illegal activities to support their crack use and frequently trade sex for the drug. ${ }^{124-126}$ Approximately one third of these individuals had recently been victims of violence or witnessed a death. ${ }^{126}$ The five-year mortality rate in a group of crack users $(n=131)$ hospitalized for detoxification in the City of São Paulo between 1992 and 1994 was 21 percent, ${ }^{127}$ which has been said to be the highest mortality rate in cocaine users in the world. ${ }^{128}$ Studies have also found that most of those deaths were caused by homicide. ${ }^{129}$ These results show a strong relationship between crack use and violence, as well as social exclusion and neglect. The use of crack cocaine leads to severe dependence and is also associated with increased drug trafficking in the regions where it occurs. ${ }^{124-126}$

\section{Treatment Protocols and Professional Training}

Brazil has no treatment protocols for health professionals working in the field of addiction, nor for those working at the primary care level. ${ }^{130}$ Considering its continental proportion, the use of telemedicine for education, training and professional consultation has begun to gain attention. ${ }^{131}$ Several universities, as well as SENAD, offer short courses on the topic, many of them online. ${ }^{132}$ Universities offer postgraduate courses regulated by the Ministry of Education providing an academic title as Specialist for those working in substance use treatment, however no structured educational or training program has been developed nationally. The Brazilian Medical Association (AMB) has developed guidelines for the treatment of problems related to substance use, ${ }^{133}$ but these have not been adopted by the federal government. 


\section{DISCUSSION}

In spite of the efforts made over the past few decades, Brazil still has a long way to go in terms of the comprehensiveness and effectiveness of its drug policy. A notable exception is Brazilian tobacco control policy, which is one of the most advanced in the world, and has managed to reduce the number of smokers by one half over the past 30 years. ${ }^{25}$ However, tobacco is still the cause of approximately 200,000 deaths a year in the country, ${ }^{134}$ and specific control policies are required to address some patterns of tobacco use, namely: (1) an increase in heavy tobacco use in women, ${ }^{135}$ and (2) persistent use in rural areas and among individuals with lower education levels, who appear to be less responsive to current tobacco control policy. ${ }^{136}$ Furthermore, access to tobacco dependence treatment is still not universal. ${ }^{27}$ Lastly, the tobacco industry must be continuously monitored to prevent companies from finding and exploiting loopholes in the current legislation. ${ }^{137}$

Unlike tobacco control legislation, alcohol control policies are still in their infancy. One of the barriers to their development is the fact that a large portion of the population associates alcohol with entertainment, and among poorer individuals, alcohol is used as a way to escape problems or cope with stress. ${ }^{35}$ For young people, bars are synonymous with fun and socialization. ${ }^{138}$ The result of an unregulated market and the strong influence of the alcohol industry has been a consistent increase in alcohol consumption in Brazil over the past 20 years, likely due to a combination of advertising, low cost and high availability. ${ }^{41}$

In response to the increase in the recreational use of prescription drugs, countries such as the United States have enhanced the monitoring of prescription patterns and pharmacy refills to avoid doctor shopping and drug diversion. ${ }^{139}$ On the Brazilian side, however, there is no periodic disclosure by health authorities on the commercial movement of these products, making the situation seem to be under control. Although internet sales of prescription drugs are not currently monitored in Brazil, ANVISA has identified a growing number of websites that sell pharmaceutical drugs, and has also found that at least one quarter of the psychotropic drugs and steroids sold over the internet (which account for 67\% of total internet drug sales) are fake or have been illegally obtained. ${ }^{140}$

Although there are currently 3.5 million regular cannabis users and 1.5 million individuals with cannabis dependence in Brazil, ${ }^{80}$ there are no treatment programs geared specifically toward this population. In recent years, debates have focused mainly on the civil rights implications of cannabis use rather than its role as a potential cause of dependence and numerous comorbidities. ${ }^{141}$ This issue has been made more complex by the fact that 
clinical trials of medical cannabinoid drugs are mistaken for studies of the cannabis plant, masking the harmful consequences of the use of this drug. ${ }^{142}$ The recent legalization of cannabis in the American States of Washington and Colorado, ${ }^{143}$ as well as the pending approval of similar laws in Uruguay,,${ }^{144}$ led to many discussions regarding the legalization of the drug in Brazil, although these have not effected any changes in the current legislation.

A number of public sector problems contributed to Brazil's emergence as the largest consumer of crack cocaine in the world. ${ }^{84}$ The social impact of crack cocaine use has significantly influenced the development of treatment services for individuals with substance disorders at municipal, state and federal levels.

However, the establishment of a treatment network has faced a number of structural, technical and ideological difficulties. So far, the CAPS-AD centers have proved unable to meet user demands and to cope with the social and regional diversity in the country. ${ }^{14,145}$ CAPS-AD have many different responsibilities and a work team of health professionals that require long and continuous training. ${ }^{146}$ Despite having a large number of potential clients, CAPS-AD do not seem to be the point of contact for those with serious dependence problems. These individuals often lack institutional connections, deal with high levels of social exclusion and discrimination, and engage in illegal activities which disfavor encounters with health services. ${ }^{113,114}$ This is aggravated by the fact that, although the CAPS-AD centers were originally designed to assist those more complicated cases with higher rates of non-adhesion to treatment, ${ }^{145}$ these facilities have become a gateway for individuals with substance abuse disorders in general, resulting in long waitlists for the original target population for these services. ${ }^{114,147}$ Lastly, the communication between CAPS-AD centers and the primary health network is poor to non-existent, as is the association between CAPS services and hospitalization facilities. ${ }^{109,113}$

According to the federal government and some Brazilian states, public service programs for substance use and dependence are based on a harm reduction approach, ${ }^{148}$ reflecting models adopted in Europe, Canada and the US in the 1980s to combat the increasing prevalence of AIDS, Hepatitis $\mathrm{C}$ and other bloodborne diseases, which affected a large number of intravenous drug users during that period. However, the target population for the Brazilian service is much more diverse, and includes users of many different substances, each associated with distinct pharmacological and sociocultural characteristics, and with varying levels of substance use severity. The strategies implemented in Brazil may also differ from those adopted elsewhere in that, although they are described as "harm reduction" approaches, this term is often used to refer to a wide range of management 
strategies, including demand and supply reduction approaches. ${ }^{149}$ Moreover, the impact of these initiatives on public health or on the consumption patterns of the users of PASs remains unknown. In this sense, global strategies end up reduced to isolated initiatives, such as the distribution of disposable pipes and cocoa butter for crack users, ${ }^{150}$ without scientific basis or specific goals in these interventions, raising questions about their ability to successfully lead patients to long-term treatment.

The Brazilian harm reduction movements, strongly grounded in the ideas of Franco Basaglia (1924-1980) and Michel Foucault (1926-1984), both of whom were key figures in the psychiatric reform movements of the 1980s, usually believe that the establishment of detoxification centers or of an association between the public health care system and therapeutic communities-at least a few of which are strongly based on concepts developed by Maxwell Jones (1907-1990) — symbolize a return to the asylum system, ${ }^{114,151}$ and that drug testing, even in very specific situations, represents a threat to civil rights. ${ }^{152}$ These individuals also consider abstinence-based programs to be unrealistic, and believe their goals to be unachievable. ${ }^{153}$ Lastly, the coercive treatment for cases of severe substance use disorderswhose clinical, public health, ethical and legal issues are often debated in the US and Europe ${ }^{154}$ in order to develop or improve appropriate protocols for its precise utilization-is simply considered by harm reduction advocates to be an infringement of individual rights, and is at times compared to the solitary confinement and torture utilized during the military regime. ${ }^{151,155}$

The role of harm reduction models in the treatment of substance dependence has been described by McKeganey as follows: “... [the harm reduction model] now finds itself at a crossroads where its proponents will need to make a choice between finding a way of aligning their ideas, policies and practices with the new found emphasis on abstinence and recovery or risk further marginalization from the mainstream of UK drug policy by focusing first and foremost on advocating for drug policy reform." ${ }^{156}$ While this scenario is evident in the Brazilian reality, there is an aggravating factor: in Brazil, harm reduction is often used as a substitute for supply and demand reduction strategies, which are thought to be archaic, ineffective and authoritarian. ${ }^{155}$

Structurally, although Brazil has a National Secretary on Drug Policy as well as a strategic plan for the implementation of programs regarding PAS use, legislative decisions on the topic are also performed by other government departments, such as the Ministry of Health and the Ministry of Justice, resulting in a lack of leadership in the development of national drug policy. ${ }^{157}$ 
Despite the recent economic development and improvement in quality of life, homicides and violence are still common in Brazil. ${ }^{122}$ Although there is a clear relation between drug trafficking, organized crime and violence, many still do not consider law enforcement agencies to be efficient in investigating and persecuting these crimes. ${ }^{158}$ Such disparagement is due in part to the recurrent use of police force-working in isolation and in a disorderly manner - to target drug trafficking, while in actuality almost always punishing users and their social ills. ${ }^{159}$ Additionally, the frequency with which law enforcement officers and politicians are found to be involved in drug trafficking rings causes many citizens to assume that the relationship between these public service sectors and illegal drug activity is inevitable and irreversible, often leading to two polarized conclusions: to either leave it as it is, since nothing can be done about it, or to the idea that only the legalization of drug use could eliminate this evil. ${ }^{158}$ However, drug enforcement strategies, such as tracking drug markets, working in strict accordance with legal procedures and bringing social improvements to individuals and communities affected by drug use, have been found to be associated with significant improvements in the violence rates, ${ }^{160,161}$ and should be included in any serious drug policy plan.

\section{CONCLUSIONS}

In spite of these difficulties, current drug policy in Brazil is in much better shape than it was 30 years ago, and still continues to improve. The presence of conceptual confusions, and ideological transpositions without a proper technical filter, as well as, the absence of clear ways of developing policy and management of resources will certainly delay the establishment of effective health care programs that combine supply, demand and harm reduction approaches and that are capable of contributing to overcome regional differences and to promote social equality in Brazil. On the other hand, awareness of the importance of working with priority-setting approaches, establishing evaluation criteria-such as effectiveness, deliverability and equity —as well as pursuing a more rational use of funds, has grown among Brazilian researchers, ${ }^{131,132}$ and should work as a source of guidance, debate and evaluation of drug policy and public health. ${ }^{162}$ 


\section{Acronyms List:}

ANVISA = The National Agency for Sanitary Surveillance

$\mathrm{BDZ}=$ Benzodiazepines

CAPS-AD = Psychosocial Care Centers for Alcohol and Drugs

FEBRACT $=$ The Brazilian Federation of Therapeutic Communities

HDI = Human Development Index

II BNADS $=$ The Second Brazilian National Alcohol and Drugs Survey

INPAD $=$ The National Institute of Science and Technology for Public Policy on

Alcohol and Other Drugs

PAS = psychoactive substance

SENAD = The National Secretary on Drug Policy

Conflicts of Interest: None declared.

\section{REFERENCES}

1. The Brazilian Institute of Geography and Statistics. Censo demográfico 2010 - características da população e dos domicílios. Rio de Janeiro: IBGE; 2011. [In Portuguese]

2. The World Bank. GDP (current US\$). Available from URL: http://data. worldbank.org/indicator/NY.GDP.MKTP.CD (Accessed 13 February 2014).

3. United Nations Development Programme. Human Development Report 2013 - the rise of the south: human progress in a diverse world. Available from URL: http://www.undp.org/content/dam/philippines/docs/HDR/HDR2013\% 20Report\%20English.pdf (Accessed 1 July 2013).

4. Paim J, Travassos C, Almeida C, Bahia L, Macinko J. The Brazilian health system: history, advances, and challenges. Lancet. 2011;377:1778-97.

5. The Brazilian Institute of Geography and Statistics. PIB dos municípios revela concentração e desigualdades na geração de renda. Available from URL: http://saladeimprensa.ibge.gov.br/noticias?view=noticia\&id=1\&busca=1\&i dnoticia=354 (Accessed 13 February 2014). [In Portuguese]

6. United Nations Development Programme - Brazilian Office. Relatório de desenvolvimento humano - Brasil 2005: racismo, pobreza e violência. Brasilia: PNUD Brasil; 2005. [In Portuguese]

7. Bethell L. On democracy in Brazil - past and present. London: Institute of Latin American Studies; 1994.

8. Power TJ, Zucco Jr. C. Elite preferences in a consolidating democracy: the Brazilian legislative surveys, 1990-2009. Lat Am Polit Soc. 2012;54:1-27.

9. Hagopian F. Paradoxes of democracy and citizenship in Brazil. Lat Am Res Rev. 2011;46:216-27.

10. European Commission. Brazil - country strategy paper 2007-2013. Available from URL: http://eeas.europa.eu/brazil/csp/07_13_en.pdf (Accessed 15 June 2013). 
11. The Economist. Democracy Index 2012: Democracy is at a standstill. Available from URL: https://www.eiu.com/public/topical_report.aspx ?campaignid=De mocracyIndex 12 (Accessed 20 July 2013).

12. Koonigs K. Strengthening citizenship in Brazil's democracy: local participatory governance in Porto Alegre. Bull Lat Am Res. 2004;23:79-99.

13. Fernandes RR, Sousa HR, Ramos FS. Are the law, democracy and socioeconomic factors related to the level of corruption in Brazilian states? Available from URL: http://www.anpec.org.br/encontro2008/artigos/200807211718170-.pdf (Accessed 28 June 2013).

14. Laranjeira R, Mitsuhiro SS. Addiction research centres and the nurturing of creativity. National institute on alcohol and drugs policies, Brazil. Addiction. 2012;107:727-32.

15. Monteiro CA, Benicio MH, Iunes R, Gouveia NC, Taddei JA, Cardoso MA. Nutritional status of Brazilian children: trends from 1975 to 1989. Bull World Health Organ. 1992;70:657-66.

16. Raw M, Laranjeira R. Brazil takes steps to control tobacco. BMJ. 1995;311:1046.

17. Szklo AS, de Almeida LM, Figueiredo VC, Autran M, Malta D, Caixeta R, et al. A snapshot of the striking decrease in cigarette smoking prevalence in Brazil between 1989 and 2008. Prev Med. 2012;54:162-7.

18. Sebrie EM, Glantz SA. "Accommodating" smoke-free policies: tobacco industry's Courtesy of Choice programme in Latin America. Tob Control. 2007; 16:e6.

19. Bialous SA, Presman S, Gigliotti A, Muggli M, Hurt R. A resposta da indústria do tabaco à criação de espaços livres de fumo no Brasil. Rev Panamericana Salud Publica = Pan Am J Public Health. 2010;27:283-90. [In Portuguese]

20. Bialous SA, Martins S. Brazil: Sao Paulo takes the lead. Tob Control. 2009; 18:341.

21. Presidency of the Republic of Brazil. Lei $N^{\circ} 12.546$ de 2011. Available from URL: http://www.planalto.gov.br/ccivil_03/leis/19294.htm (Accessed 29 June 2013). [In Portuguese]

22. Brazilian Ministry of Health. Resolução - RDC No 14, de 15 de março de 2012. Available from URL: http://bvsms.saude.gov.br/bvs/saudelegis/anvisa/2012/ rdc0014_15_03_2012.html (Accessed 13 February 2014). [In Portuguese]

23. Lee K, Chagas LC, Novotny TE. Brazil and the framework convention on tobacco control: global health diplomacy as soft power. PLoS Med. 2010;7: e1000232.

24. Presidency of the Republic of Brazil. Decreto No 5.658, de 2 de janeiro de 2006. Available from URL: http://www.planalto.gov.br/ccivil_03/_Ato20042006/2006/Decreto/D5658.htm (Accessed 25 February 2014). [In Portuguese]

25. Monteiro CA, Cavalcante TM, Moura EC, Claro RM, Szwarcwald CL. Population-based evidence of a strong decline in the prevalence of smokers in Brazil (1989-2003). Bull World Health Organ. 2007;85:527-34. 
26. Almeida L, Szklo A, Sampaio M, Souza M, Martins LF, Szklo M, et al. Global Adult Tobacco Survey data as a tool to monitor the WHO Framework Convention on Tobacco Control (WHO FCTC) implementation: the Brazilian case. J Environ Res Public Health. 2012;9:2520-36.

27. Raw M, McNeill A, Murray R. Case studies of tobacco dependence treatment in Brazil, England, India, South Africa and Uruguay. Addiction. 2010;105: 1721-8.

28. Morton J, Song Y, Fouad H, Awa FE, Abou El Naga R, Zhao L, et al. Crosscountry comparison of waterpipe use: nationally representative data from 13 low and middle-income countries from the Global Adult Tobacco Survey (GATS). Tobacco control. 2013; epub ahead of print.

29. Jurberg C. Brazil and tobacco use: a hard nut to crack. Bull World Health Organ. 2009;87:812-3.

30. Laranjeira R, Pinsky I, Sanches M, Zaleski M, Caetano R. Alcohol use patterns among Brazilian adults. Rev Bras Psiquiatr. 2010;32:231-41.

31. Castro DS, Sanchez ZM, Zaleski M, Alves HN, Pinsky I, Caetano R, et al. Sociodemographic characteristics associated with binge drinking among Brazilians. Drug Alcohol Depend. 2012;126:272-6.

32. Caetano R, Mills B, Pinsky I, Zaleski M, Laranjeira R. The distribution of alcohol consumption and the prevention paradox in Brazil. Addiction. 2012; 107:60-8.

33. Pinsky I, Sanches M, Zaleski M, Laranjeira R, Caetano R. Patterns of alcohol use among Brazilian adolescents. Rev Bras Psiquiatr. 2010;32:242-9.

34. Carlini ELA, Noto AR, Sanchez ZVDM, Carlini CMA, Locatelli DP, Abeid LR, et al. VI levantamento nacional sobre o consumo de drogas psicotrópicas entre estudantes do ensino fundamental e médio das redes pública e privada de ensino nas 27 capitais brasileiras. Brasilia: SENAD; 2010. [In Portuguese]

35. Laranjeira R, Romano M. Brazilian consensus on public policies on alcohol. Rev Bras Psiquiatr. 2004;26:68-77.

36. Duailibi S, Laranjeira R. [Alcohol-related public policies]. Rev Saude Publica. 2007;41:839-48. [In Portuguese]

37. Pinsky I, Laranjeira R. Alcohol in Brazil: recent public health aspects. Addiction. 2004;99:524.

38. Pinsky I, Laranjeira R. Ethics of an unregulated alcohol market. Addiction. 2007;102:1038-9; discussion 9-40.

39. Campos VR, de Souza ESR, Duailibi S, Laranjeira R, Palacios EN, Grube JW, et al. Drinking and driving in southeastern Brazil: results from a roadside survey study. Addict Behav. 2013;38:1442-7.

40. Seligman, M., 2005. Alcoolismo e responsabilidade social. Presented at the International Forum of Quality of Life and Health - Alcoholism: Who Pays the Bill?, Porto Alegre, Brazil, April 8.

41. Laranjeira R, Hinkley D. Evaluation of alcohol outlet density and its relation with violence. Rev Saude Publica. 2002;36:455-61. 
42. Romano M, Duailibi S, Pinsky I, Laranjeira R. [Alcohol purchase survey by adolescents in two cities of State of Sao Paulo, Southeastern Brazil]. Rev Saude Publica. 2007;41:495-501. [In Portuguese]

43. São Paulo State Government. Lei No 14.592 de 19 de outubro de 2011. Available from URL: http://www.alcoolparamenoreseproibido.sp.gov.br/wp-content/ uploads/pl698a11-parcial.pdf (Accessed 13 February 2014). [In Portuguese]

44. Departamento Nacional de Trânsito. Frota brasileira de veículos - 2013. Available from URL: http://www.denatran.gov.br/frota2013.htm (Accessed 23 July 2013) [In Portuguese]

45. Instituto de Pesquisa Econômica Aplicada, Departamento Nacional de Trânsito. Impactos sociais e econômicos dos acidentes de trânsito nas rodovias brasileiras. Brasilia: IPEA/DENATRAN/ANTP; 2006. [In Portuguese]

46. Bacchieri G, Barros AJ. Traffic accidents in Brazil from 1998 to 2010: many changes and few effects. Rev Saude Publica. 2011;45:949-63.

47. de Carvalho Ponce J, Munoz DR, Andreuccetti G, de Carvalho DG, Leyton V. Alcohol-related traffic accidents with fatal outcomes in the city of Sao Paulo. Accid Anal Prev. 2011;43:782-7.

48. Abreu AMM, Lima JMB, Matos LN, Pillon SC. [Alcohol use and traffic accidents: a study of alcohol levels]. Rev Latino-Am Enfermagem. 2010;18: 513-20. [In Portuguese]

49. Santos Modelli ME, Pratesi R, Tauil PL. [Blood alcohol concentration in fatal traffic accidents in the Federal District, Brazil]. Rev Saude Publica. 2008;42: 350-2. [In Portuguese]

50. Dualibi S, Pinsky I, Laranjeira R. Prevalence of drinking and driving in a city of Southeastern Brazil. Rev Saude Publica. 2007;41:1058-61.

51. Massara VM. Brief synopsis of the Brazilian freight transport and future development. J Infrastructure Dev. 2012;4:77-90.

52. Departamento Nacional de Trânsito. Lei № 11.705 de 19 de junho de 2008 . Available from URL: http://www.denatran.gov.br/publicacoes/download/ctb _e_legislacao_complementar.pdf(Accessed 13 February 2014). [In Portuguese]

53. Mello Jorge MHP, Koizumi MS. Acidentes de trânsito causando vítimas: possível reflexo da lei seca nas internações hospitalares. Rev ABRAMET. 2009;27:16-25. [In Portuguese]

54. Campos VR, de Souza e Silva R, Duailibi S, dos Santos JF, Laranjeira R, Pinsky I. The effect of the new traffic law on drinking and driving in Sao Paulo, Brazil. Accid Anal Prev. 2013;50:622-7.

55. Pinsky I, Labouvie E, Pandina R, Laranjeira R. Drinking and driving: predriving attitudes and perceptions among Brazilian youth. Drug Alcohol Depend. 2001;62:231-7.

56. Pechansky F, Chandran A. Why don't northern American solutions to drinking and driving work in southern America? Addiction. 2012;107:1201-6.

57. Laranjeira R, Marques AC, Ramos Sde P, Campana A, Luz E, Jr., Franca J. Who runs alcohol policy in Brazil? Addiction. 2007;102:1502-3. 
58. Hayashi N. Beer beats oil as AmBev value rises toward top: corporate Brazil. Available from URL: http://www.bloomberg.com/news/2012-06-18/beerbeats-oil-as-ambev-value-rises-toward-top-corporate-brazil.html (Accessed 20 June 2012).

59. Caetano R, I. P, Laranjeira R. Should soccer and alcohol mix? Alcohol sales during the 2014 World Soccer Cup games in Brazil. Addiction. 2012;107:17223.

60. Vendrame A, Pinsky I. [Inefficacy of self-regulation of alcohol advertisements: a systematic review of the literature]. Rev Bras Psiquiatr.. 2011;33:196-202.

61. Pantani D, Sparks R, Sanchez ZM, Pinsky I. 'Responsible drinking' programs and the alcohol industry in Brazil: killing two birds with one stone? Soc Sci Med. 2012;75:1387-91.

62. Wolburg JM. How responsible are "responsible" drinking campaigns for preventing alcohol abuse? J Consum Mark. 2005;22:176-7.

63. de Andrade AG. Ethics of alcohol policy in Brazil: why it is possible to be independent when we sit at the same table with the alcohol industry. Addiction. 2008;103:854-5.

64. Diadema - Police Department. Violence records, Diadema: 1995-2005. Diadema: Diadema Police Department; 2005.

65. Duailibi S, Ponicki W, Grube J, Pinsky I, Laranjeira R, Raw M. The effect of restricting opening hours on alcohol-related violence. Am J Public Health. 2007;97:2276-80.

66. Carvalho MF, Pascom AR, Souza-Junior PR, Damacena GN, Szwarcwald CL. Utilization of medicines by the Brazilian population, 2003. Cadernos Saude Publica. 2005;21 Suppl:100-8.

67. Pereira FS, Bucaretchi F, Stephan C, Cordeiro R. Self-medication in children and adolescents. J Pediatria. 2007;83:453-8.

68. Kapczinski F, Amaral OB, Madruga M, Quevedo J, Busnello JV, de Lima MS. Use and misuse of benzodiazepines in Brazil: a review. Subst Use Misuse. 2001;36:1053-69.

69. Noto AR, Carlini EA, Mastroianni PC, Alves VC, Galduróz JCF, Kuroiwa W, et al. Analysis of prescription and dispensation of psychotropic medications in two cities in the State of São Paulo, Brazil. Rev Bras Psiquiatr 2002;24:6873.

70. Orlandi P, Noto AR. [Misuse of benzodiazepines: a study among key informants in São Paulo city]. Rev Latino-Am Enfermagem. 2005;13:896-902. [In Portuguese]

71. Spanemberg L, Nogueira EL, da Silva CT, Dargel AA, Menezes FS, Cataldo Neto A. High prevalence and prescription of benzodiazepines for elderly: data from psychiatric consultation to patients from an emergency room of a general hospital. Gen Hosp psychiatry. 2011;33:45-50.

72. Nappo SA, de Oliveira EM, Morosini S. Inappropriate prescribing of compounded antiobesity formulas in Brazil. Pharmacoepidemiol Drug Saf. 1998;7:207-12. 
73. Carneiro MFG, Guerra Júnior AA, Acurcio FA. [Prescription, dispensing, and regulation of psychoactive anorexigenic drugs in Belo Horizonte, Minas Gerais, Brazil]. Cad Saúde Pública. 2008;24:1763-72. [In Portuguese]

74. Agência Nacional de Vigilância Sanitária. Resolução - RDC No 52, de 6 de outubro de 2011. Available from URL: http://www.anvisa.gov.br/hotsite/ anorexigenos/pdf/RDC\%2052-2011\%20DOU\%2010\%20de\%20outubro\%20 de\%202011.pdf (Accessed 1 July 2013). [In Portuguese]

75. Mariotti Kde C, Ortiz RS, Souza DZ, Mileski TC, Froehlich PE, Limberger RP. Trends in counterfeits amphetamine-type stimulants after its prohibition in Brazil. Forensic Sci Int. 2013;229:23-6.

76. Itaborahy C, Ortega F. [Methylphenidate in Brazil: a decade of publications]. Ciênc Saúde Coletiva. 2013;18:803-16. [In Portuguese]

77. Palhares-Alves HN, Vieira DL, Laranjeira RR, Vieira JE, Nogueira-Martins LA. Clinical and demographic profile of anesthesiologists using alcohol and other drugs under treatment in a pioneering program in Brazil. Rev Bras Anestesiologia. 2012;62:356-64.

78. Carlini EA, Galduróz JCF, Silva AAB, Noto AR, Fonseca AM, Carlini CM, et al. II levantamento domiciliar sobre o uso de drogas psicotrópicas no Brasil: estudo envolvendo as 108 maiores cidades do país. São Paulo: CEBRID/ SENAD; 2006. [In Portuguese]

79. Bastos FI, Bertoni N, Hacker MA, Grupo de Estudos em Populacao SeA. [Drug and alcohol use: main findings of a national survey, Brazil 2005]. Rev Saude Publica. 2008;42 Suppl 1:109-17. [In Portuguese]

80. Instituto Nacional de Ciência e Tecnologia para Políticas Públicas do Álcool e Outras Drogas. II levantamento nacional de álcool e drogas - o uso de maconha no Brasil. Available from URL: http://inpad.org.br/wp-content/ uploads/2013/04/Press_Maconha_SIte1.pdf (Accessed 18 July 2013). [In Portuguese]

81. Zanatta K, Almeida AO, Pinheiro A, Michelotti G. Será que vicia? Universidade cria ambulatório para usuários de maconha e reacende polêmica sobre a droga Available from URL: http://www1.folha.uol.com.br/revista/rf 1302200004.htm (Accessed 13 February 2014). [In Portuguese]

82. Jungerman FS, Laranjeira R. Characteristics of cannabis users seeking treatment in Sao Paulo, Brazil. Rev Panamericana Salud Publica = Pan Am J Public Health. 2008;23:384-93.

83. United Nations Office on Drug and Crime. World Drug Report - 2010. Vienna: United Nations; 2010.

84. Abdalla RR, Madruga CS, Ribeiro M, I. P, Caetano R, Laranjeira R. Prevalence of cocaine use in Brazil: data from the II Brazilian National Alcohol and Drugs Survey (BNADS). Addict Behav. 2014;39:297-301.

85. United Nations Office on Drug and Crime. World Drug Report - 2012. Vienna: United Nations; 2012.

86. Duailibi LB, Ribeiro M, Laranjeira R. Profile of cocaine and crack users in Brazil. Cadernos Saude Publica. 2008;24 Suppl 4:s545-57. 
87. Carvalho HB, Bueno R. Infecção pelo HIV e seus determinantes em sete cidades brasileiras. In: Mesquita F, Seibel S, (editors). Consumo de drogas: desafios e perspectivas. São Paulo: Hucitec; 2000. p. 21-53. [In Portuguese]

88. Hacker MA, Leite IC, Renton A, Torres TG, Gracie R, Bastos FI. Reconstructing the AIDS epidemic among injection drug users in Brazil. Cadernos Saude Publica. 2006;22:751-60.

89. Lampe E, Espirito-Santo MP, Martins RM, Bello G. Epidemic history of Hepatitis C virus in Brazil. Infect Genet Evol. 2010;10:886-95.

90. Barbosa Junior A, Szwarcwald CL, Pascom ARP, Souza Junior PB. [Trends in the AIDS epidemic in groups at highest risk in Brazil, 1980-2004]. Cadernos Saude Publica. 2009;25:727-37. [In Portuguese]

91. Pechansky F, Woody G, Inciardi J, Surratt H, Kessler F, Von Diemen L, et al. HIV seroprevalence among drug users: an analysis of selected variables based on 10 years of data collection in Porto Alegre, Brazil. Drug Alcohol Depend. 2006;82 Suppl 1:S109-13.

92. Hacker MA, Leite I, Friedman SR, Carrijo RG, Bastos FI. Poverty, bridging between injecting drug users and the general population, and "interiorization" may explain the spread of HIV in southern Brazil. Health Place. 2009; 15:5149.

93. Barrionuevo A. Ecstasy ensnares upper-class teenagers in Brazil Available from URL: http://www.nytimes.com/2009/02/15/world/americas/15ecstasy.html? pagewanted=all\&_r=1\& (Accessed 1 August 2013).

94. de Almeida SP, Silva MT. Ecstasy (MDMA): effects and patterns of use reported by users in Sao Paulo. Rev Bras Psiquiatr. 2003;25:11-7.

95. Battisti MC, Noto AR, Nappo S, Carlini Ede A. A profile of Ecstasy (MDMA) use in Sao Paulo, Brazil: an ethnographic study. J Psychoactive Drugs. 2006; 38:13-8.

96. Paulin LF, Turato ER. [The prelude to psychiatric reform in Brazil: the contradictions of the 1970s]. Hist Cienc Saude-Manguinhos. 2004;11:24158. [In Portuguese]

97. Fusar-Poli P, Bruno D, Machado-De-Sousa JP, Crippa J. Franco Basaglia (1924--1980): three decades (1979--2009) as a bridge between the Italian and Brazilian mental health reform. Int J Soc Psychiatry. 2011;57:100-3.

98. Mari Jde J, Saraceno B, Rodriguez J, Levav I. Mental health systems in Latin America and Caribbean countries: a change in the making. Psychol Med. 2007;37:1514-6.

99. Caldas de Almeida JM, Horvitz-Lennon M. Mental health care reforms in Latin America: an overview of mental health care reforms in Latin America and the Caribbean. Psychiatr Serv. 2010;61:218-21.

100. Csillag C. Psychiatric reform law comes into effect in Brazil. Lancet. 2001;357: 1346.

101. Andreoli SB, Almeida-Filho N, Martin D, Mateus MD, Mari Jde J. Is psychiatric reform a strategy for reducing the mental health budget? The case of Brazil. Rev Bras Psiquiatr. 2007;29:43-6. 
102. Laranjeira R, Elbreder MF, Perrenoud LO, Ribeiro M. Moradias assistidas para dependentes químicos. In: Ribeiro M, Laranjeira R, (editors). O tratamento do usuário de crack. Porto Alegre: Artmed; 2012. p. 514-9.

103. Brazilian Ministry of Health. Reforma psiquiátrica e política de saúde mental no Brasil. Available from URL: http://bvsms.saude.gov.br/bvs/publicacoes/ relatorio15_anos_caracas.pdf (Accessed 27 June 2013). [In Portuguese]

104. Brazilian Ministry of Health. Saúde mental no SUS: os centros de atenção psicossocial. Available from URL: http://www.ccs.saude.gov.br/saude_ mental/pdf/sm_sus.pdf (Accessed 29 July 2013). [In Portuguese]

105. Número de vagas está longe do previsto e prometido. Em Discussão - Rev Audiências Públicas Senado Federal 2011;8:38. [In Portuguese]

106. Brazilian Ministry of Health. Consultórios de rua do SUS. Available from URL: http://portal.saude.gov.br/portal/arquivos/pdf/consult_rua17_1_11.pdf (Accessed 7 July 2013). [In Portuguese]

107. Larrobla C, Botega NJ. Restructuring mental health: a South American survey. Soc Psychiatry Psychiatr Epidemiol. 2001;36:256-9.

108. Duailibi LB, Ribeiro M. Enfermaria especializada. In: Ribeiro M, Laranjeira R, (editors). O tratamento do usuário de crack. Porto Alegre: Artmed; 2012. p. 540-7. [In Portuguese]

109. Reabilitação desafia a sociedade. Em Discussão - Rev Audiências Públicas Senado Federal. 2011;8:32-5. [In Portuguese]

110. Comunidades oferecem $80 \%$ das vagas e querem ajuda do Estado. Em Discussão - Rev Audiências Públicas Senado Federal. 2011;8:60-2. [In Portuguese]

111. Siqueira MM, Barbosa DA, Laranjeira R, Hopkins K. Psychoactive substances and the provision of specialized care: the case of Espirito Santo. Rev Bras Psiquiatr. 2007;29:315-23.

112. Fracasso L, Landre M. Comunidade terapêutica. In: Ribeiro M, Laranjeira R, (editors). O tratamento do usuário de crack. Porto Alegre: Artmed; 2012. p. 503-13. [In Portuguese]

113. Ilha F, E. R. No RS, dois terços das comunidades não têm condições para funcionar. Available from URL: http://oglobo.globo.com/pais/no-rs-doistercos-das-comunidades-nao-tem-condicoes-para-funcionar-9218458 (Accessed 29 July 2013). [In Portuguese]

114. Laranjeira R, Zaleski M. Políticas públicas. In: Ribeiro M, Laranjeira R, (editors). O tratamento do usuário de crack. Porto Alegre: Artmed; 2012. p. 633-52. [In Portuguese]

115. Iniciativas de assistência e reinserção social ainda engatinham. Em Discussão - Rev Audiências Públicas Senado Federal 2011;8:55-6. [In Portuguese]

116. Ribeiro MM. Aspectos legais. In: Silveira DX, Moreira FG, (editors). Panorama atual de drogas e dependência. São Paulo: Atheneu; 2006. p. 46976. [In Portuguese]

117. Secretaria Nacional sobre Drogas. Legislação e políticas públicas sobre drogas no Brasil. Brasilia: SENAD; 2010. [In Portuguese] 
118. Geffray C. Social, economic and political impacts of drug trafficking in the state of Rondônia, in the Brazilian Amazon. In: Geffray C, Fabre G, Schiray $\mathrm{M}$, (editors). Globalisation, drugs and criminalization - final research report on Brazil, China, India and Mexico. Marseille: UNESCO/MOST; 2001.

119. Mingardi G. Money and the international drug trade in Sao Paulo. Int Soc Sci J. 2001;53:379-86.

120. Zaluar A. Violence in Rio de Janeiro: styles of leisure, drug use, and trafficking. Int Soc Sci J. 2001;53:369-78.

121. Sapori LF, Sena LL, Silva BFA. A relação entre o comércio do crack e a violência urbana na região metropolitana de Belo Horizonte. In: Sapori LF, Medeiros R, (editors). Crack - um desafio social. Belo Horizonte: Editora PUC Minas; 2010. p. 38-80. [In Portuguese]

122. Ribeiro WS, Mari Jde J, Quintana MI, Dewey ME, Evans-Lacko S, Vilete LM, et al. The impact of epidemic violence on the prevalence of psychiatric disorders in Sao Paulo and Rio de Janeiro, Brazil. PloS One. 2013;8:e63545.

123. Drugs in Brazil - cracking up. Available from URL: http://www.economist. com/news/americas/21575810-worlds-biggest-crack-market-seeks-betterway-deal-addicts-cracking-up (Accessed 12 July 2013).

124. Paim Kessler FH, Barbosa Terra M, Faller S, Ravy Stolf A, Carolina Peuker A, Benzano D, et al. Crack users show high rates of antisocial personality disorder, engagement in illegal activities and other psychosocial problems. Am J Addict. 2012;21:370-80.

125. Santos Cruz M, Andrade T, Bastos FI, Leal E, Bertoni N, Villar LM, et al. Key drug use, health and socio-economic characteristics of young crack users in two Brazilian cities. Int J Drug Policy. 2013;24:432-8.

126. Duailibi L, Ribeiro M, Laranjeira R. [Sociodemographic study with crack users from Luz District - downtown São Paulo City ("Cracolândia”)]. Available from URL: www.inpad.org.br (Accessed 12 July 2013). [In Portuguese]

127. Ribeiro M, Dunn J, Laranjeira R, Sesso R. High mortality among young crack cocaine users in Brazil: a 5-year follow-up study. Addiction. 2004;99:11335 .

128. Degenhardt L, Singleton J, Calabria B, McLaren J, Kerr T, Mehta S, et al. Mortality among cocaine users: a systematic review of cohort studies. Drug Alcohol Depend. 2011;113:88-95.

129. Ribeiro M, Dunn J, Sesso R, Dias AC, Laranjeira R. Causes of death among crack cocaine users. Rev Bras Psiquiatr. 2006;28:196-202.

130. Goncalves DA, Fortes S, Campos M, Ballester D, Portugal FB, Tofoli LF, et al. Evaluation of a mental health training intervention for multidisciplinary teams in primary care in Brazil: a pre- and posttest study. Gen Hosp Psychiatry. 2013;35:304-8.

131. Tomlinson M, Rudan I, Saxena S, Swartz L, Tsai AC, Patel V. Setting priorities for global mental health research. Bull World Health Organization. 2009;87: 438-46. 
132. Secretaria Nacional sobre Drogas. Capacitação. Available from URL: http:// portal.mj.gov.br/senad/main.asp?ViewID=\%7B3A1B2C37-4B6D-4C9280F8-6BD24F53CBAF\%7D\&params=itemID=\%7B3DE302EF-93BE4BF5-8921-C45C762640D9\%7D;\&UIPartUID=\%7B2868BA3C-1C724347-BE11-A26F70F4CB26\%7D (Accessed 23 June 2013). [In Portuguese]

133. Associação Médica Brasileira. Projeto diretrizes. Available from URL: http:// www.projetodiretrizes.org.br/amb.php (Accessed 3 June 2013). [In Portuguese]

134. Instituto Nacional de Câncer. Tabagismo - um grave problema de saúde pública. Rio de Janeiro: INCA; 2007. [In Portuguese]

135. Instituto Nacional de Câncer. Pesquisa Especial de Tabagismo (PETab) relatório Brasil. Rio de Janeiro: INCA; 2011. [In Portuguese]

136. Azevedo e Silva G, Valente JG, Almeida LM, Moura EC, Malta DC. Tobacco smoking and level of education in Brazil, 2006. Rev Saude Publica. 2009;43 Suppl 2:48-56.

137. Pantani D, Pinsky I, Monteiro A. Publicidade de tabaco no ponto de venda. São Paulo: INPAD; 2011. [In Portuguese]

138. Caetano R, Laranjeira R. A 'perfect storm' in developing countries: economic growth and the alcohol industry. Addiction. 2006;101:149-52.

139. Holmes D. Prescription drug addiction: the treatment challenge. Lancet. 2012; 379:17-8.

140. Fagundes LL, Karl FJ, Silva PC, Leite VM. Comércio ilegal de medicamentos pela Internet: um estudo de caso. Available from URL: http://www.icofcs. org/2012/ICoFCS2012_05.pdf(Accessed 13 February 2014). [In Portuguese]

141. Noto AR, Pinsky I, Mastroianni Fde C. Drugs in the Brazilian print media: an exploratory survey of newspaper and magazine stories in the year 2000 . Subst Use Misuse. 2006;41:1263-76.

142. Crippa JA, Hallak JE, Zuardi AW. Marijuana, feijoada and the debate on drug legalization. Front Psychiatry. 2013;4:7.

143. Hawken A, Caulkins J, Kilmer B, Kleiman M. Quasi-legal cannabis in Colorado and Washington: local and national implications. Addiction. 2013;108:837-8.

144. How will Uruguay's marijuana law work? Available from URL: http://www. economist.com/blogs/economist-explains/2013/08/economist-explains-1 (Accessed 10 August 2013).

145. Andrade TM. [Reflections on drug policies in Brazil]. Ciênc Saúde Coletiva. 2011;16:4665-74. [In Portuguese]

146. Conselho Regional de Medicina do Estado de São Paulo. Avaliação dos centros de atenção psicossocial (CAPS) do Estado de São Paulo. São Paulo: CREMESP; 2010. [In Portuguese]

147. Ribeiro M, Perrenoud LO. Ambulatório especializado: estrutura, funcionamento e indicações. In: Ribeiro M, Laranjeira R, (editors). O tratamento do usuário de crack. Porto Alegre: Artmed; 2012. p. 521-30. [In Portuguese] 
148. Teixeira LP. Bangkok 2004. The spread of harm-reduction programs in Brazil. HIV/AIDS policy \& law review / Canadian HIV/AIDS Legal Network. 2004;9:94-5.

149. Room R. Working towards harm reduction in Brazil. Addiction. 2002;97:14889.

150. Domanico A, Malta M. Implementation of harm reduction toward crack users in Brazil: barriers and achievements. Subst Use Misuse. 2012;47:535-46.

151. Conselho Federal de Psicologia. Relatório da $4^{\mathrm{a}}$ inspeção nacional de direitos humanos: locais de internação para usuários de drogas. Available from URL: http://www.crpsp.org.br/portal/midia/pdfs/Relatorio_Inspecao_Direitos_ Humanos.pdf (Accessed 13 Februrary 2014). [In Portuguese]

152. Curso de Extensão Universitária 'Drogas e Direitos humanos' PCeDU, ,. Declaração de direitos dos usuários de drogas por uma política de redução dos danos. Available from URL: http://www.flacso.org.br/portal/pdf/area saude_publica_direitos_humanos/2008_DECLARACAO_DIREITOS DOS_USUARIOS_DROGAS.pdf (Accessed 13 February 2014). [In Portuguese]

153. Santos VE, Soares CB, Campos CMS. [Harm reduction: analysis of the concepts that guide practices in Brazil]. Physis. 2010;20:995-1015. [In Portuguese]

154. Kallert TW, Mezzich JE, Monahan J. Coercive treatment in psychiatry clinical, legal and ethical aspects. Hoboken (NJ): Wiley-Blackwell; 2011.

155. Lancetti A, Chioro A, Vargas B, Zaparoli C, Petuco DRS, Castilho EWV, et al. Drogas e cidadania: em debate. Brasilia: CFP; 2012. [In Portuguese]

156. McKeganey N. Harm reduction at the crossroads and the rediscovery of drug user abstinence. Drugs Educ Prev Pol. 2012;19:276-83.

157. Pulverizados, órgãos e iniciativas não conseguem se articular. Em Discussão - Rev Audiências Públicas Senado Federal. 2011;8:50. [In Portuguese]

158. Boyum DA, Caulkins JP, Kleiman MAR. Drugs, crime and public policy. In: Wilson JQ, Petersilla J, (editors). Crime and public policy. New York (NY): Oxford University Press; 2011. p. 368-410.

159. Wacquant L. The militarization of urban marginality: lessons from the Brazilian metropolis. Int Pol Sociology. 2008;2:56-74.

160. Strang J, Babor T, Caulkins J, Fischer B, Foxcroft D, Humphreys K. Drug policy and the public good: evidence for effective interventions. Lancet. 2012;379:71-83.

161. Briggs D. Crack cocaine users: high society and low life in South London. London: Routledge; 2011.

162. da Costa e Silva VL, Pantani D, Andreis M, Sparks R, Pinsky I. Bridging the gap between science and public health: taking advantage of tobacco control experience in Brazil to inform policies to counter risk factors for noncommunicable diseases. Addiction. 2013;108:1360-6. 